Trinity College

Trinity College Digital Repository

Faculty Scholarship

$10-2003$

The Art of the 'Impossible': Writing Peace Agreements During War

Andrew Flibbert

Trinity College, andrew.flibbert@trincoll.edu

Follow this and additional works at: https://digitalrepository.trincoll.edu/facpub

Part of the Education Commons 


\title{
The Art of the 'Impossible': Writing Peace Agreements During War
}

\author{
Andrew Flibbert, Trinity College and New York University
}

\section{Introduction}

Teaching about war and peace in the Middle East, South Asia, and the Islamic world has perhaps never been more difficult, discouraging, and vital to American higher education. Student interest in these areas has surged considerably in the wake of September 11th, the wars in Afghanistan and Iraq, Indian-Pakistani nuclear brinkmanship, and renewed Palestinian-Israeli violence. As teachers, we face daunting challenges in devising constructive approaches to such controversial, highly politicized, and emotionally charged issues. Traditional pedagogy may not suffice, especially if it ignores the growing wellspring of student energy and concern that-if tapped effectivelycan be parlayed into significant learning. Writing peace agreements is one way of winning students' best efforts during the worst of times.

A focus on peace accords may seem inappropriate, premature, or even belated for some contemporary conflicts. Ongoing Palestinian-Israeli violence has followed the decade-long "peace process" of the 1990s, transforming the landscape of relationships, attitudes, and interests. But this assignment is directed less toward the process of conflict resolution per se and more toward discerning the eventual substantive outcome of future talks. While Palestinians and Israelis may seem to have crossed the Rubicon toward permanent hostility, the very nature of the conflict suggests that eventually they will find themselves back at the negotiating table. Even if the latest talks fail, students are poorly served by a wait-and-see response to the problems of war and peace; now is the time for innovative thinking and teaching.

Accordingly, I have developed a constructive approach in which students write comprehensive peace agreements tackling Palestinian-Israeli relations, the entire Middle East, or the PakistaniIndian conflict over Kashmir. For nonarea specialists, a scaled-down version of the assignment might be suitable in introductory undergraduate international

Andrew Flibbert is visiting assistant professor at Trinity College and an adjunct professor at New York University. relations courses. The approach could be adapted to any number of conflicts, but it lends itself best to high-stakes disputes that are longstanding, seemingly intractable, implicated in both domestic and international politics, involving concerns over identity as well as territory, and for which the major claims of both parties are well defined and appear legitimate. By contrast, this approach would not be suitable for amorphous, asymmetric conflicts (e.g., the "war on terrorism"), for structural antagonisms that may not be fully resolvable by negotiation (e.g., the Cold War), or if one side will not participate in a negotiated settlement.

I designed the assignment specifically for two upper-level undergraduate courses on the Middle East, which I taught at Brown University and Williams College. The success of this approach was evident not just in the students' enthusiastic comments and evaluations, but also in their genuinely impressive achievements in completing the task itself. I am sharing my experiences here because I suspect that relatively few political scientists currently use this teaching method. I will show its effectiveness by elaborating on four sets of benefits that were apparent from my experiences, and by clarifying the assignment's underlying rationale. Then I will offer some practical advice on how to develop your own version, and how to modify it for various conflicts.

\section{Benefits and Rationale}

\section{You can't fail us}

First, writing peace agreements empowers and energizes students in ways that more straightforward lectures, discussions, case studies, and even roleplaying or simulation cannot. ${ }^{1}$ Initial student reaction to the assignment invariably was one of trepidation mixed with skeptical astonishment: "We have to come up with a solution to the conflict?!" But the difficulty of the task is liberating, and ultimately it elicited the best efforts of a great majority of students. Few dared to procrastinate in tackling such a daunting project, and word got back to me that students were talking about it with their friends and other professors. With a little guidance and encouragement, their concern soon turned into enthusiasm. In a counterintuitive sense, asking the impossible takes some pressure off. As one student declared at the outset, "You can't fail us if we fail this thing!"

Indeed, no one failed. The greatest difficulty that students experienced was in balancing the incommensurable tradeoffs inherent in multifaceted negotiations. If Israel compromises on settlements, for example, what exactly is that worth in terms of Palestinian concessions on, say, a right of return? In making such judgments, the most successful agreements avoided crossing political red lines while forging connections among the dazzling array of issues. Not surprisingly, students found that compromise on single, discrete issues was much harder without linking these issues to others. A trade-off on Israeli water rights and access, for example, could be achieved more easily by associating it with Palestinian sovereignty-at least in principle-over its subterranean natural resources. A political division of Jerusalem, some found, was untenable unless tied to carefully considered provisions to assure freedom of movement and the protection of holy sites.

\section{Active Engagement}

Second, the assignment allows students to work through an enormously complex set of material in an active, creative, and constructive manner. They learn the nuts and bolts of the conflict. They decide how all the details relate to a larger whole that they must devise themselves, within the narrow confines of political reality. They take charge of the substantive issues, detailing a vision of order and justice that makes sense to them. They are empowered to make any choices they deem necessary and wise, but are constrained by the conflict's relatively fixed set of circumstances. Having a specific purpose in mind helps students stay focused, gives them an Archimedean point from which 
to approach the issues, and keeps them from getting lost in a sea of unfamiliar names, places, and events.

Ideally, the assignment should create a dynamic and multidimensional learning process that requires students to master the substantive issues and rearrange them in a manner sensitive to the hopes and fears of both sides. In the Palestinian-Israeli context, most of the negotiating issues have been on the table for over a decade, so students have little difficulty identifying them and discerning the basic positions of the major political actors. Admittedly, the national consensus constraining or enabling a peace agreement has shifted substantially on each side over the years, creating a moving target of sorts. But rather than reading passively about how

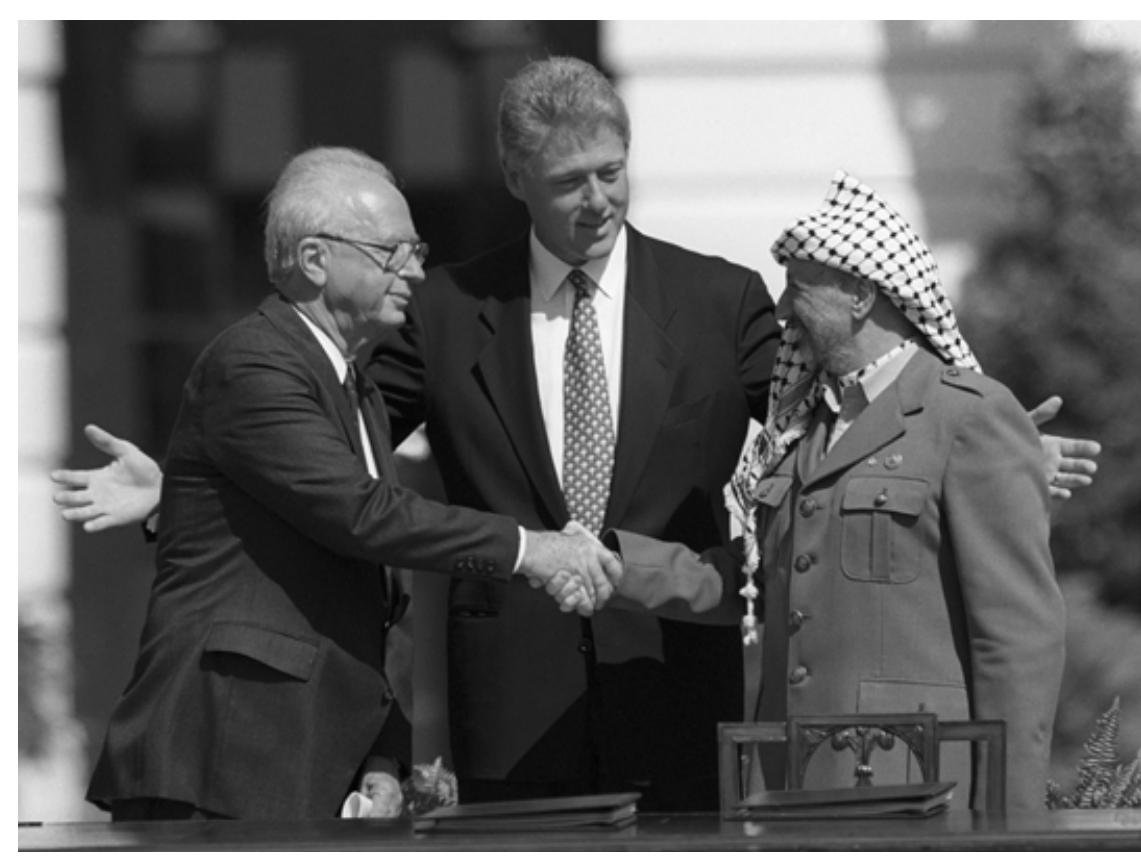

The Peace Process. Students in Flibbert's class must find a lasting solution, something Clinton, shown here brokering a 1993 accord with Rabin and Arafat, could not do. Photo: AP/Ron Edmonds. ciently compelling to provoke or inspire a measure of dedicated engagement.

To create viable peace agreements, students must also learn about a host of related political concepts, ranging from the traditional (sovereignty, the security of multiple constituencies. Successful completion of the assignment came from accommodating such demands, thereby channeling student efforts in politically constructive directions. Ardent Zionists and devoted Palestinian nationalists alike had to build a peace with the principal touchstone of political sustainability. I told my students that the problem had many conceivable solutions: a peace agreement is less like a jigsaw puzzle and more like a tapestry. If politics is the art of the possible, they had to weave together all the elements in a way that would survive the acid test of political durability.

Of course, maintaining a future accord is not the same as achieving it. Peace and conflict resolution, somewhat like democracy and democratization, have distinct substantive and procedural di- and why earlier at-

tempts at conflict resolution have failed, students are responsible for imagining the conditions under which a new consensus in both communities could form. Even if students get some of the details wrong, they are sure to benefit from the effort.

\section{Something for Everyone}

Invariably, the assignment yielded a variety of final outcomes, as students focused on different aspects of the peace agreement and called on their own particular talents and inclinations. Some students made hand-drawn maps, showing enormous artistic skill and creativity. One geosciences major researched the underground aquifers at the heart of bilateral water conflict. A young engineer contemplated the design of a raised highway linking Gaza and the West Bank. Another student-now working on Capitol Hill-took great care to use the precise language of a well-crafted political agreement. Indeed, there is something for everyone. Quite obviously, the multifaceted nature of the conflict produces many stumbling blocks to a peaceful resolution. Yet, this also increases the likelihood that most students will find some aspect of it suffi- dilemma, nationalism, party politics) to more cutting-edge concerns (human security, refugee rights, terrorism, the revolution in military affairs). At the outset, I invoked the logic of two-level games to emphasize the cross-cutting negotiating imperatives facing political leaders (Putnam 1988; Evans, Jacobson, and Putnam 1993). All of this might seem overwhelming for most undergraduates, but the potential payoff is enormous. Students consistently reported that they came to a much better understanding of concepts like Westphalian sovereignty after considering how to enable or constrain the sovereignty of a fledgling Palestinian state. Those with an interest in elections and party politics benefited from grappling with the dilemmas facing Israeli coalition governments. The exercise therefore proved remarkably useful in helping students integrate conceptual abstractions with rich historical materials.

\section{The Art of the Possible}

Finally, the assignment offers a much-needed antidote to the pessimistic primordialism that tempts newcomers and non-specialists in Middle East politics. Durable peace accords, by definition, must satisfy the minimal demands mensions - the difference between what they are and how to get or remain there. Some students struggled with the assignment's focus on peace as an outcome or endpoint, wanting to introduce process-oriented elements, such as the gradual building of trust between the antagonists or the strict sequencing of issues on the negotiating agenda. But imagining what the outcome would look like at the conclusion of a successful peace process permitted students to do what many negotiators in the Middle East have avoided for years. They constructed a plausible and just peace, in all its devilish details. This, in itself, was worth the price of admission.

In the end, students took away from the assignment a sober awareness of the difficulty of achieving peace. This is much needed by those who trivialize the Arab-Israeli conflict by framing it in terms of personal disagreements or reducing it to the playground antics of disobedient children. Presumably, some of this learning will translate into a general appreciation for the intractability of other longstanding political disputes. That said, many students also gained a surprising optimism about the possibilities for peace in the Middle East. This is especially important for those who 
have been taught that regional conflict is a product of inherent cultural antagonism or "age-old" rivalry. Their optimism may not have been entirely misplaced, but even if it was, this is less dangerous than the cynical indifference that comes with writing off human conflict.

\section{A 'How To'}

Here are a few suggestions for how to make this assignment work.

1. Starting Out. Give students detailed written instructions and some preliminary guidance regarding the substantive issues. Depending on the course structure, you may want to discuss all the issues in class while students work individually on the assignment. Avoid giving too much specific advice or students will conclude that you have only one solution in mind. Remind those students expressing highly partisan perspectives of their obligation to anticipate the other side's reaction. Play devil's advocate by echoing the most persuasive arguments made by both sides.

2. Structure and Content. Include very specific minimum requirements for addressing - one way or another-all the major bones of contention between the parties. Insist that students break down their agreements into manageable and appropriate subsections, reminding them that this is not a conventional research paper or essay. For Palestinian-Israeli relations, the most significant issues are as follows:

- Personal and national security arrangements for both nationalities.

- The status of Jerusalem, including the Old City and religious sites.

- The status of Israeli settlements in the West Bank, Gaza, and East Jerusalem.

- The existence and location of bypass roads and checkpoints.

- The nature of sovereignty and its constraints for both states.

- Rights of return for both nationalities.

- Palestinian refugees in the West
Bank, Gaza, and neighboring states.

- Water rights and usage.

- Border demarcations, airspace, and territorial access.

- Israeli and Palestinian military deployments and limitations.

- The status of political prisoners and security detainees.

3. Assumptions and Hypothetical Scenarios. Lay out a set of guiding assumptions relating to, for example, potential international financial support to defray the costs of eventual implementation, the extent and nature of American or U.N. involvement, and the state of broader Arab-Israeli negotiations. You may wish to write a short, future-oriented hypothetical scenario, putting aside current negotiations if they are active. Even if what you devise is highly improbable in certain ways, it is necessary to structure the larger assignment. An abbreviated example is as follows: "It is May 2004, and unprecedented violence between Israelis and Palestinians has led to a renewed consensus on the desirability of resolution to the conflict. You are the chief arbitrator of a newly constituted international body. You have been empowered by the U.N. Security Council, the recently elected government of Israel, and the reformed Palestinian National Authority to devise a comprehensive, detailed, fair, and permanent solution to the Israeli-Palestinian conflict. Propose such a solution in the form of a peace agreement. The agreement will be submitted to both national communities for full acceptance or rejection by referenda, without modification or further negotiation. If it passes both referenda, implementation will begin immediately."

4. Guiding Criteria. Emphasize that peace agreements must a) be satisfactory to an absolute majority of Israelis and Palestinians, enabling both parties to sign on; b) anticipate all major objections and criticisms-except those by irredentists and peace rejectionists on either side; c) include creative but feasible solutions to these objections. Remind students to focus on outcome over process; these are peace agreements, not full-blown plans for implementing them.

5. Language and Style. Require that the agreements be written in suitable language. Students should consult and emulate other peace agreements in this regard, though my preference is to avoid excessively technical or legalistic jargon in order to keep the focus on substantive political concerns. ${ }^{2}$ Excellent maps and other peace accords are readily available online and in standard reference materials. ${ }^{3}$

6. Group Projects. Consider making this a group project, though subject to all the usual disadvantages of individual shirking, dominant personalities, excessive conformity, and "risky shift." ${ }^{4}$ If using groups, a division of labor by issue-area or negotiating party is not recommended. Division by issue-area reduces the opportunity for each student to contend with both the agreement as a whole and all of its constituent parts; division by negotiating party eliminates the obligation to imagine and accommodate the other side's perspective. Still, a small group format would have the advantages of a) easing the burden for students in an introductory-level class; b) creating a forum for debating the issues; and c) requiring compromise as a prerequisite to the assignment's successful completion. One might even contemplate using small groups to combine an initial classroom simulation with the subsequent writing of peace agreements.

7. Feedback and Grading. Be prepared to provide students with detailed written feedback. This is essential, since otherwise they will not know what, in your judgment, worked and what was less persuasive. Your comments obviously should address their handling of specific issues (e.g., what to do about refugees), as well as the broader political calculation embodied in their work (i.e., whether both sides might conceivably accept it). Your overall assessment may be somewhat subjective, but the chief purpose of the assignmentunlike peace agreements themselves-is to start a learning process that promises results regardless of the final outcome.

\section{Notes}

1. For a valuable recent discussion of simulations, see Beth K. Dougherty, "Byzantine Politics: Using Simulations to Make Sense of the Middle East," PS: Political Science and Politics 36 (April 2003): 239-244.

2. Most of the relevant prior agreements and U.N. Security Council resolutions are contained in Charles D. Smith, Palestine and the ArabIsraeli Conflict: A History with Documents, 4th edition, (New York: Bedford/St. Martin's, 2001).
Other relevant items are available in the online appendix to William Quandt's Peace Process: American Diplomacy and the Arab-Israeli Conflict since 1967, Revised edition, (Washington, D.C.: Brookings Institution Press and Berkeley: University of California Press, 2001). See www.brookings.edu/press/appendix/ peace_process.htm.

3. See, for example, the Perry-Castañeda Library Map Collection at the University of
Texas: http://www.lib.utexas.edu/maps/ middle_east.html or the website of Le Monde Diplomatique: http://mondediplo.com/maps.

4. Students-like all people-might be less risk averse in a group setting, feeling relatively invulnerable in small-group decision-making. In this instance, they might be inclined to devise more "radical" peace agreements that could prove less tenable. 


\section{References}

Evans, Peter B., Harold K. Jacobson, and Robert D. Putnam, eds. 1993. Double-Edged Diplomacy: International Bargaining and
Domestic Politics. Berkeley: University of California Press.

Putnam, Robert D. 1988. "Diplomacy and
Domestic Politics: The Logic of Two-Level Games." International Organization 42 (summer): 427-460. 